\title{
Psoriasiform spongiotic dermatitis
}

\author{
Bayu Sutarjono, ${ }^{1,2}$ Herman Lebovitch ${ }^{1}$
}

${ }^{1}$ Department of Internal Medicine, Brookdale University Hospital Medical Center, Brooklyn, New York, USA ${ }^{2}$ Saba University School of Medicine, Devens, Massachusetts, USA

\section{Correspondence to}

Bayu Sutarjono,

b.sutarjono@saba.edu

Accepted 19 February 2019

\section{DESCRIPTION}

A 55-year-old homeless man with AIDS and history of psoriasis presented with generalised skin lesions. $\mathrm{He}$ reported pink rashes appearing on the legs 8 months ago. It spread with severe itching and scaling, and exacerbated into erythematous papular infiltrated skin lesions over the arms, legs and torso that coalesced into plaques and hardened. $\mathrm{He}$ had difficulty ambulating but denied joint pain or stiffness.

Physical examination revealed large, thick darkbrown hyperkeratotic plaques with a tree barklike appearance on the legs (figure 1A-E); thick concentric verruciform plaques on the forearms (figure 1F, G); hyperpigmented patches, spotted with pink papules, topped by circumferential lichenification and converging into larger silver crusted plaques on the torso, neck and head (figure $1 \mathrm{H}$ ) and lesion-free genitalia. Lesions were adherent and odourless without expressing discharge or fluid. Pink rashes were present on the upper arms, hands and feet (figure 1I-K), accompanied by hyperkeratotic soles and palms (figure $1 \mathrm{~K}, \mathrm{~L}$ ). Nails of hands showed nail bed hyperkeratosis, onycholysis and 'oil drop' dyschromia, an orange-yellow discolouration beneath the nail plate (figure 1J). Nails of feet exhibited onychogryphosis, defined by subungual keratosis, opaque yellow-brown discolouration of the nail plate and twisted, hyperkeratotic nails resembling 'rams' horns' (figure $1 \mathrm{~K}$ ).

The patient was afebrile with a CD4 count of 9 cells $/ \mu \mathrm{L}$ (normal $500-1500$ cells $/ \mu \mathrm{L}$ ) and viral count of 59700 copies $/ \mathrm{mL}$. All other laboratory studies were unimpressive. Wound culture grew Staphylococcus aureus, while acid-fast bacilli, fungal and blood cultures were negative. Following dermatology consultation, a skin punch-hole biopsy

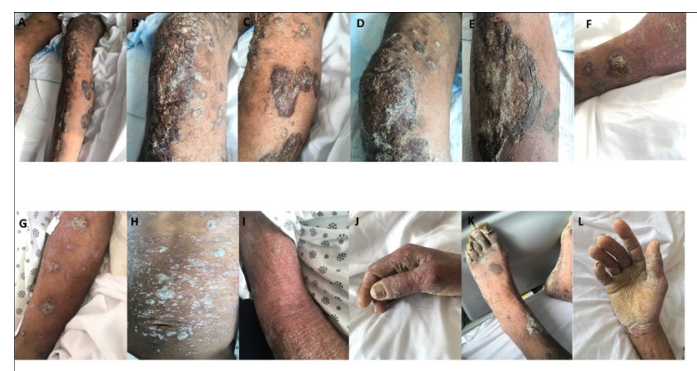

(c) BMJ Publishing Group Limited 2019. No commercial re-use. See rights and permissions. Published by BMJ.

To cite: Sutarjono B, Lebovitch H. BMJ Case Rep 2019;12:e228690. doi:10.1136/bcr-2018228690
Figure 1 Skin lesions of the left lower leg $(A-C)$, right lower leg $(D, E)$, dorsal surface of the right forearm $(F)$, ventral surface of the left forearm $(\mathrm{G})$ and abdomen $(\mathrm{H})$. Rash on the ventral surface of the right upper arm (I). Nail psoriasis and rash on the dorsal aspects of the right hand $(\mathrm{J})$ and left foot $(\mathrm{K})$. Hyperkeratosis of the soles $(\mathrm{K})$ and right palm (L). of the right dorsal wrist was performed. No other bedside tests were conducted.

In consideration to his living situation and immune status, our differential diagnoses included Norwegian scabies, an ectoparasitic infection by Sarcoptes scabiei forming warty, hyperkeratotic lesions; and cutaneous blastomycosis, a deep fungal infection by Blastomyces dermatitidis presenting as crusted nodules and plaques with indurated borders. Alternatively, we contemplated rupioid psoriasis, characterised by thick cone-shaped lesions resembling limpets; or ostraceous psoriasis, distinguished by oyster shell-like lesions with concave centres. Histologically, they show abnormal keratinized squamae with inflammation and seroexudate. Reactive or psoriatic arthritis would have been considered had joint involvement been present. Other possibilities included mycosis fungoides, a primary cutaneous lymphoma masquerading as scaly, infiltrative and converging plaques; and lichen planus, consisting of polygonal, pruritic and planar plaques. Biopsy proved negative for fungal elements using periodic acid-Schiff and Grocott methenamine silver stains but revealed dense hyperkeratosis overlying coalescing parakeratosis, acanthosis, scant intraepidermal intercellular oedema and dermal lymphocytic infiltrates, consistent with the diagnosis of psoriasiform spongiotic dermatitis.

Psoriasiform spongiotic dermatitis, an inflammatory dermatosis, manifests from conditions like psoriasis, nutritional deficiencies and $\mathrm{HIV}_{0}{ }^{1}{ }^{2}$ It distributes symmetrically on elbows, knees, scalp and torso, ${ }^{2}$ and excoriation of lesions leads to superinfection. It combines features of psoriasiform

\section{Learning points}

- Individuals with the combination of immunodeficiency, nutritional deficiency and psoriasis are at risk of developing psoriasiform spongiotic dermatitis.

- Differential diagnoses include Norwegian scabies, cutaneous blastmycosis, rupioid psoriasis, ostraceous psoriasis, reactive arthritis, psoriatic arthritis, mycosis fungoides and lichen planus.

- It combines histopathological features of psoriasiform dermatitis (characterised by regular epidermal hyperplasia and club-shaped dermal papillae, dilated papillary blood vessels and normal subpapillary blood vessels) and spongiotic dermatitis (defined by intraepidermal intercellular oedema, sparse dermal inflammatory infiltrate and slight dilatation of subpapillary vessels). 
dermatitis, characterised by regular epidermal hyperplasia or acanthosis, and spongiotic dermatitis, defined by intraepidermal intercellular oedema and the exocytosis of lymphocytes. ${ }^{3}$ Chronic spongiotic dermatitis acquires psoriasiform configuration over time, with diminishing spongiosis and more prominent epidermal acanthosis. ${ }^{2}$

Topical glucocorticoids and antiretroviral treatment were given, and the patient improved markedly 3 weeks later.

Acknowledgements We express our gratitude to Srishti Visen, MD, Irene Rahman, MD, Muhammad Khan, MD and Alemante Kassa, MD, who provided excellent care for this patient.

Contributors BS drafted manuscript and provided images. HL edited and approved the manuscript.
Funding The authors have not declared a specific grant for this research from any funding agency in the public, commercial or not-for-profit sectors.

Competing interests None declared.

Patient consent for publication Not required.

Provenance and peer review Not commissioned; externally peer reviewed.

\section{REFERENCES}

1 LeBoit PE. Dermatopathologic findings in patients infected with HIV. Dermatol Clin 1992;10:59-71.

2 Wick MR. Psoriasiform dermatitides: a brief review. Semin Diagn Pathol 2017;34:220-5.

3 Ackerman AB. An algorithmic method for histologic diagnosis of inflammatory and neoplastic skin diseases by analysis of their patterns. Am J Dermatopathol 1985;7:105-207.

Copyright 2019 BMJ Publishing Group. All rights reserved. For permission to reuse any of this content visit

https://www.bmj.com/company/products-services/rights-and-licensing/permissions/

BMJ Case Report Fellows may re-use this article for personal use and teaching without any further permission.

Become a Fellow of BMJ Case Reports today and you can:

- Submit as many cases as you like

- Enjoy fast sympathetic peer review and rapid publication of accepted articles

- Access all the published articles

- Re-use any of the published material for personal use and teaching without further permission

For information on Institutional Fellowships contact consortiasales@bmjgroup.com

Visit casereports.bmj.com for more articles like this and to become a Fellow 